\title{
Early Markets: Fuel Cells for Backup Power
}

\section{Overview}

Hydrogen can be used to power nearly every end-use energy need. Fuel cells - which directly convert the chemical energy in hydrogen to electricity with only water and heat as byproducts - are the key to making it happen.

Hydrogen polymer electrolyte membrane (also called proton exchange membrane or "PEM") fuel cells are leading candidates for use in fuel cell vehicles. Although it will be a while before fuel cell vehicles reach every dealer showroom, PEM fuel cells are commercially available today for certain applications. One of these near-term markets is emergency backup power.

Today's commercially available PEM fuel cells are particularly appropriate for low-power applications (generally less than 5 kilowatts) requiring intermittent backup. This includes a wide range of communication and data control systems for which backup power is essential.

\section{The Case for Fuel Cells}

Backup power technologies currently include batteries and generators operating on diesel, propane, or gasoline. Most backup power communication and control systems use a combination of generators and batteries to provide redundancy to avoid service disruptions. Although these systems are reliable and well established, concerns with batteries and generators are encouraging customers to seek out alternatives that provide high reliability and durability at a reasonable cost.
Compared to batteries, fuel cells offer longer continuous runtime and greater durability in harsh outdoor environments under a wide range of temperature conditions. With fewer moving parts, they require less maintenance than both generators and batteries. They can also be monitored remotely, reducing actual maintenance time. Compared to generators, fuel cells are quieter and have no emissions.

PEM fuel cells can also offer significant cost advantages over both battery-generator systems and battery-only systems when shorter run-time capability of up to three days is sufficient. In a study for the U.S. Department of Energy, Battelle Memorial Institute analyzed lifecycle costs of emergency response radio towers, comparing fuel cells with $2 \mathrm{~kW}$ battery-only backup of 8 hours and $5 \mathrm{~kW}$ batterygenerator backup of 52 hours, 72 hours, and 176 hours. As shown in the table below, on a lifecycle basis, PEM fuel cells can provide service at substantially lower total cost than current technologies (the higher cost of the 176-hour fuel cell system results from the cost of hydrogen storage tank rental).
Net Present Value in Dollars of Total Cost of Backup Power Systems for Emergency Response Radio Towers

\begin{tabular}{|l|c|c|c|c|c|c|}
\hline & \multicolumn{3}{|c|}{ OUTDOOR INSTALLATIONS } & \multicolumn{3}{c|}{ INDOOR INSTALLATIONS } \\
\cline { 2 - 7 } & $\begin{array}{c}\text { BATTERY/ } \\
\text { GENERATOR }\end{array}$ & $\begin{array}{c}\text { PEM FUEL } \\
\text { CELL } \\
\text { WITHOUT TAX } \\
\text { INCENTIVE }\end{array}$ & $\begin{array}{c}\text { PEM FUEL } \\
\text { CELL WITH TAX } \\
\text { INCENTIVE }\end{array}$ & $\begin{array}{c}\text { PEM FUEL } \\
\text { BATTERY } \\
\text { ONLY } \\
\text { CELL } \\
\text { WITHOUT TAX } \\
\text { INCENTIVE }\end{array}$ & $\begin{array}{c}\text { PEM FUEL } \\
\text { CELL WITH TAX } \\
\text { INCENTIVE }\end{array}$ \\
\hline 8-hour run time & & & $\$ 19,037$ & $\$ 14,023$ & $\$ 12,136$ \\
\hline 52-hour run time & $\$ 61,082$ & $\$ 61,326$ & $\$ 56,609$ & & & \\
\hline 72-hour run time & $\$ 47,318$ & $\$ 33,901$ & $\$ 32,014$ & & & \\
\hline 176-hour run time & $\$ 75,575$ & $\$ 100,209$ & $\$ 95,491$ & & & \\
\hline
\end{tabular}

Source: Identification and Characterization of Near-term Direct Hydrogen Proton Exchange Membrane Fuel Cell Markets, Battelle Memoria Institute (April 2007)

Notes:

1. Total cost includes capital costs and operations and maintenance costs.

2. Fuel cell systems with tax incentive prices are calculated with benefit of a tax credit of up to $\$ 1000 / \mathrm{kW}$ enacted by the Energy Policy Act of 2005.

3. Calculations assume a 5-year battery replacement schedule. Analysis of 3-year replacement schedules (for cold or harsh environments) indicates PEM fuel cells compare more favorably to traditional technologies. 


\section{Practical Use}

To provide instant start capability, fuel cell systems are paired with batteries or ultracapacitors and typically include power electronics and hydrogen fuel storage. Hydrogen is typically supplied and stored at the point of use as a compressed gas. A number of delivery options are available from commercial gas companies working in partnership with the fuel cell manufacturers.

Several government facilities are already using or have tested fuel cells as backup power for communications and other systems. The State of Maryland currently uses a fuel cell backup power system at a wireless communications microwave site at Elk Neck State Park near North East, Maryland. The Elk Neck tower, which consists of a single-channel microwave repeater radio tower, supports several tenants, including the State's E-911 Communications System. During Hurricane Isabel (2003) and its aftermath, the fuel cell system enabled critical radio communications over the microwave network for Maryland State Police and emergency medical response services until primary grid power was restored.

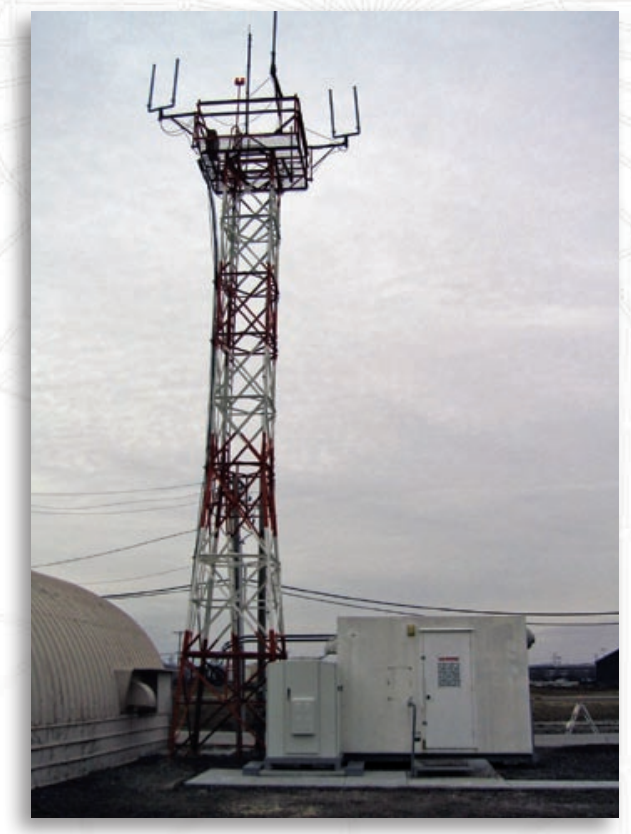

A 1-kW fuel cell system has been providing power for this Federal Aviation Administration radio tower near Chicago for more than 3 years. The hydrogen storage and delivery system and fuel cell itself are all contained in the smaller cabinet closer to the tower.

Photo courtesy of Relion
Contacts

DOE Hydrogen Program Peter Devlin Phone: 202-586-4905 Email: peter.devlin@ee.doe.gov

Battelle Memorial Institute Kathya Mahadevan Statistics and Information Analysis

Phone: 614-424-3197

Email: mahadevank@battelle.org

To read the full report, Identification and Characterization of Near-term Direct Hydrogen Proton Exchange Membrane Fuel Cell Markets, completed by Battelle Memorial Institute for the U.S. Department of Energy, please visit www.eere.energy. gov/hydrogenandfuelcells/fc_ publications.html.

Increase Your H2IQ!

Visit www.hydrogen.energy.gov

Produced by the National Renewable Energy Laboratory (NREL)

NREL is a U.S. Department of Energy National Laboratory operated by Midwest Research Institute - Battelle 